Int. J. Electrochem. Sci., 16 (2021) Article ID: 210526

International Journal of

ELECTROCHEMICAL

SCIENCE

www.electrochemsci.org

\title{
Preparation of $\mathrm{MWCNT}-\mathrm{MnO}_{2} / \mathrm{Ni}$ foam composite electrode for electrochemical degradation of Congo red wastewater
}

\author{
Huajing Zhu* and Zeli Chen \\ School of Biology and Environmental Engineering, Tianjin Vocational Institute, Tianjin 300410, \\ China \\ *E-mail: huajingzhu1866@163.com
}

doi: $10.20964 / 2021.05 .19$

Received: 3 January 2021 / Accepted: 20 February 2021 / Published: 31 March 2021

Dye wastewater has the characteristics of high chroma, strong toxicity and difficult degradation, which has a serious impact on the environment. Because of its advantages of low energy consumption, simple operation and no secondary pollution, electrochemical oxidation technology has been increasingly studied in the field of refractory organic wastewater treatment. In this work, we report a multiwalled carbon nanotube (MWCNT)- $\mathrm{MnO}_{2}$ nanocomposite as a $\mathrm{Ni}$ foam electrode modification. Then, the MWCNT- $\mathrm{MnO}_{2} / \mathrm{Ni}$ electrode is used for the electrochemical oxidation of Congo red dye. We study the effect of various factors on the decolorization of Congo red by the single-factor method. The results show that the decolorization rate of Congo red decreases with an increasing initial concentration and $\mathrm{pH}$. In this work, hydroxyl radicals are detected by high-performance liquid chromatography. In the case of hydroxyl radicals and chloride ions acting separately, it is concluded that the indirect oxidation of chloride ions is the main mechanism during the process of electrocatalytic oxidation.

Keywords: Electrochemical oxidation; Congo red; Nanocomposite; Degradation mechanism; Multiwalled carbon nanotube

\section{FULL TEXT}

(C) 2021 The Authors. Published by ESG (www.electrochemsci.org). This article is an open access article distributed under the terms and conditions of the Creative Commons Attribution license (http://creativecommons.org/licenses/by/4.0/). 